\title{
Fatwa dalam Keuangan Syariah: Kekuatan Mengikat dan Kemungkinannya untuk Digugat Melalui Judicial Review
}

\author{
Agus Triyanta \\ Fakultas Hukum Universitas Islam Indonesia \\ Jl. Tamansiswa No. 158 Yogyakarta \\ triyantaagus@yahoo.com ; agustriyanta@uii.ac.id
}

\begin{abstract}
The main problems of this research are: first, the conceptual definition of fatwa in Islamic law in general and sharia financial law specifically; second, the legality or binding force of fatwa in sharia economic law; and third, the possibility of judicial review for fatwa issued by National Sharia Board (DSN). This research is a normative juridical study based on the primary, secondary, and tertiary legal sources. The conclusion drawn in this research is: first, fatwa is a legal opinion issued by an individual or a particular institution which has purpose or function to present any opinions regarding the matters related to life aspectsby considering the sharia principles or Islamic doctrines; second, the legality of fatwa appears due to the statement of the existing regulation stating that only fatwa issued by DSN which becomes the reference of sharia banking businesses. Even if DSN is considered as a non-government institution due to which its regulatory products do not have binding force unlike the regulations issued by the governmental institutions in general, fatwa still has its own binding nature, though substantively it is due to the existence of the Regulation of Bank of Indonesia related to the sharia banking provisions since if there is anything regarding sharia matters, Bank of Indonesia shall adopt the DSN fatwa. Third, as the consequence of the binding force, in which the government regulation might be legally reviewed, fatwa is also possible to be an object of a request for judicial review.
\end{abstract}

Key words : Fatwa, binding force, judicial review.

\begin{abstract}
Abstrak
Pokok permasalahan pada penelitian ini: Pertama, batasan konseptual tentang fatwa dalam hukum Islam umumnya atau hukum keuangan syariah pada khususnya; Kedua, legalitas atau kekuatan mengikat dari fatwa dalam bidang hukum ekonomi syariah; Ketiga, kemungkinan untuk dilakukannya peninjauan kembali (judicial review) bagi fatwa yang dikeluarkan oleh Dewan Syariah Nasional. Penelitian ini merupakan penelitian yuridis- normatif yang mendasarkan sumber datanya pada bahan hukum, baik primer, sekunder maupun tersier. Kesimpulan yang diperoleh dari penelitian ini, pertama: fatwa adalah pendapat hukum yang dikeluarkan oleh perorangan atau lembaga tertentu yang memiliki tujuan atau tugas untuk memberikan berbagai pendapat tentang persoalan terkait aspek-aspek kehidupan dengan ditinjau dari prisip-prinsip syariah atau ajaran Islam. Kedua, legalitas fatwa muncul karena adanya pernyataan dari regulasi yang ada bahwa hanya fatwa DSN lah yang menjadi rujukan dalam bisnis perbankan syariah. Bahkan, jika pun DSN itu dianggap sebagai lembaga non pemerintah yang karenanya semua produk aturan yang dikeluarkannya tidak memiliki kekuatan mengikat sebagaimana umumnya putusan lembaga pemerintahan, tetap saja fatwa itu akan mengikat, meskipun secara substantif, hal itu dikarenakan Peraturan Bank Indonesia terkait berbagai ketentuan perbankan syariah, jika menyangkut permasalahan syariah, adalah merupakan adopsi dari fatwa DSN. Ketiga, sebagai konsekuensi kekuatan yang mengikat tersebut, kemudian sebagai karakteristik sebuah regulasi pemerintah yang dapat digugat (diajukan keberatan atasnya), maka fatwa juga dapat menjadi objek dari permohonan judicial review.
\end{abstract}

Kata kunci: Fatwa, kekuatan mengikat, judicial review 


\section{Pendahuluan}

Dalam beberapa dekade terakhir ini, fatwa mendapatkan urgensinya di level global. Bukan berarti bahwa pada masa-masa sebelumnya fatwa itu tidak ada, fatwa senantiasa ada dan bermunculan sepanjang perjalanan sejarah umat Islam. Namun, haruslah diakui bahwa popularitasnya tidak setinggi jika dibandingkan dengan masa-masa terakhir ini. Berbagai analisa dan spekulasi dapat diarahkan pada fenomena ini.

Salah satu analisa utamanya adalah bahwa tingginya popularitas fatwa ini disebabkan oleh pasang-naiknya bisnis keuangan syariah secara global. Menurut data yang ada, perkembangan bisnis keuangan syariah atau keuangan Islam telah menjangkau tidak kurang dari 75 negara di wilayah yang terdapat di semua benua. Membentang sejak dari Amerika Utara, Eropa, Australia hingga ujung Afrika dan negeri Timur jauh.

Bahkan, jika diamati secara seksama, perkembangan bisnis keuangan Islam ini seakan tidak lagi mengenal latar belakang ideologi negara. Utamanya sejak perbankan Islam khususnya dan lembaga keuangan Islam pada umumnya didirikan di berbagai negara-negara seperti Hongkong, Beijing dan bahkan Moscow di Rusia, ${ }^{1}$ negera-negara yang selama ini diasumsikan sebagai sangat kental afiliasinya dengan ideologi komunisme atau sosialisme. Maka kemudian dapat diambil sebuah kesimpulan bahwa, bisnis keuangan Islam ini tidak lagi terbatas pada masyarakat dengan latar belakang ideologi dan agama tertentu, meskipun pada awalnya dirintis oleh pemeluk agama Islam.

Hal tersebut menunjukkan, bahwa apa yang banyak dipopulerkan dengan lembaga keuangan Islam (syariah) yang inklusif bukanlah sekedar wacana. Sebagaimana yang sudah banyak dipahami, yang dimaksudkan dengan bersifat inklusif adalah bahwa lembaga keuangan Islam dapat menerima dan sekaligus diharapkan dapat diterima oleh siapapun, tidak mempertimbangakan kebangsaan dan bahkan afiliasi keagamaan. Dan fenomena sebagaimana yang disebutkan di atas jelas telah menjadi eksplanasi bagi inklusifitas lembaga keuangan Islam (syariah) tersebut.

Jika dikembalikan pada naiknya popularitas fatwa, maka hal ini tidak dapat dilepaskan dari trend tersebut di atas. Sehingga pertanyaannya kemudian adalah,

\footnotetext{
1 'Global Perspective on Islamic Banking and Insurance’ in New Horizon, April-June, 2007, hlm. 24.
} 
jika bisnis keuangan syariah beroperasi di berbagai negara yang tidak familiar dengan ajaran Islam, baik karena Islam mewarnai berbagai regulasi yang ada maupun karena penduduk Muslim yang dominan, maka, atas dasar aturan apa mereka merujuk dalam hal terkait operasionalisasi prinsip-prinsip syariah dalam bisnis perbankan syariah (Islam).

Maka jawabannya hampir pasti bahwa tidak bisa tidak mereka telah dan akan selalu merujuk pada fatwa yang dikeluarkan oleh berbagai ulama atau lembaga yang reliable dan memiliki otoritas untuk mengeluarkannya. Sehingga yang menjadi pertanyaan selanjutnya adalah apa sebenarnya yang dimaksud dengan fatwa itu, siapa yang memiliki hak untuk mengeluarkan fatwa, serta atas dasar apa fatwa itu memiliki kekuatan mengikat. Dan kemudian, jika memang fatwa dalam keuangan syariah di Indonesia ini, yang mana penerbitannya hanya sah untuk dikeluarkan oleh sebuah lembaga yang bernama Dewan Syariah Nasional (DSN) dinilai memiliki fungsi kekuatan mengikat, maka apakah fatwa tersebut kemudian dapat menjadi obyek dari gugatan, atau yang sering disebut dengan judicial review? Berbagai pertanyaan ini adalah persoalan yang akan dibahas dalam artikel ini.

\section{Rumusan Masalah}

Dengan melihat uraian dalam pendahuluan tersebut, maka gambaran dari permasalahan yang dipertanyakan dalam konteks masalah ini semakin jelas. Secara rinci masalah yang dimaksud dapat dirumuskan sebagai berikut: Pertama, bagaimanakah batasan konseptual tentang fatwa dalam hukum Islam umumnya atau hukum keuangan syariah pada khususnya? Kedua, bagaimanakah legalitas atau kekuatan mengikat dari fatwa dalam bidang hukum ekonomi syariah itu? Ketiga, bagaimanakah kemungkinan untuk dilakukannya peninjauan kembali (judicial review) bagi sebuah fatwa yang dikeluarkan oleh Dewan Syariah Nasional?

\section{Tujuan Penelitian}

Dari rumusan masalah yang tertera di atas, ada beberapa tujuan dari penelitian ini. Secara rinci, tujuannya adalah sebagai berikut: Pertama, untuk merumuskan batasan konseptual atas fatwa dalam hukum Islam umumnya atau hukum keuangan syariah pada khususnya. Kedua, untuk merumuskan legalitas atau kekuatan mengikat dari fatwa dalam bidang hukum ekonomi syariah. Ketiga, untuk 
mendapatkan kejelasan ilmiah terkait dengan kemungkinan untuk dilakukannya peninjauan kembali (judicial review) bagi sebuah fatwa yang dikeluarkan oleh Dewan Syariah Nasional

\section{Metode Penelitian}

Fokus penelitian ini adalah mengetahui bagimana konsep fatwa dalam bidang hukum keuangan syariah, kekuatan mengikatnya serta kemungkinannya untuk dilakukan upaya judicial review. Jenis penelitian ini adalah penelitian normatif atau penelitian hukum doktriner. Sehingga sumber bahan hukum dari penelitian ini terdiri dari; 1). Sumber hukum primer : bahan-bahan hukum yang mempunyai kekuatan hukum mengikat seperti Al-qur'an, al-hadts, kitab-kitab klasik, fatwa dewan syari' ah, undang-undang, 2). Bahan hukum sekunder berupa literatur, jurnal dan data elektronik serta, 3). Bahan-bahan hukum tersier berupa kamus dan ensiklopedi.

Cara pengumpulan bahan hukum dilakukan melalui; 1). Studi pustaka, yakni dengan mengkaji berbagai peraturan (fatwa Dewan Syariah Nasional) atau literatur yang berhubungan dengan permasalahan yang akan diteliti, dan, 2). Studi dokumen, yakni dengan mengkaji berbagai dokumen yang terkait dengan permasalahan yang akan diteliti.

Analisis hasil penelitian dilakukan dengan cara deskriptif-analitis. Data yang terkumpul dari studi kepustakaan, dianalisis dengan metode kualitatif, yaitu datadata yang diperoleh dari hasil penelitian dikelompokkan dan dipilih, kemudian dihubungkan dengan masalah yang akan diteliti, sehingga dapat menjawab perumusan masalah yang ada. Data dihimpun dengan pengamatan yang seksama, meliputi analisis dokumen dan catatan-catatan. Penelitian kualitatif ini dengan mempergunakan cara berpikir secara induktif, yaitu pola pikir dan cara pengambilan kesimpulan yang dimulai dari suatu gejala dan fakta satu persatu, yang kemudian dapat diambil suatu generalisasi (ketentuan umum ) sebagai suatu kesimpulan. 


\section{Hasil Penelitian dan Pembahasan}

\section{Fatwa: Konsep dan Batasan}

Fatwa adalah suatu pendapat hukum (legal opinion) terhadap suatu masalah yang muncul di kalangan umat Islam, yang dikeluarkan oleh seseorang atau lembaga tertentu yang memiliki kewenangan untuk itu. ${ }^{2}$ Kewenangan, jika dilihat dari persektif fikih adalah terpenuhinya seperangkat kriteria yang harus dipenuhi agar seseorang memiliki kapasitas dan otoritas untuk melakukan ijtihad, maka hasil atau produk ijtihad tersebut kemudian menjadi fatwa. ${ }^{3}$

Dalam pengertian umum, kriteria itu menggunakan kriteria kepakaran yang diterima oleh umat Islam, tidak selamanya kriteria itu merupakan rumusan yang ditetapkan oleh sebuah kekuasaan politik, yaitu negara, atau jika pada masa lalu, dapat saja penetapan oleh khalifah, amir (gubernur) atau sultan (raja). Akan tetapi, di luar itu, fatwa juga dapat diberikan atau dikeluarkan oleh individu seorang mujtahid atau ulama. Maka dalam hal ini, pemerimaan masyarakat atas fatwa tersebut dikarenakan reputasi seorang ulama tersebut. Munculnya berbagai imam madzhab atau ulama mujtahid pada sepanjang sejarah perjalanan umat Islam adalah sebuah contoh bahwa reputasi dan kredibilitas personal seorang ulama dapat membawa pada posisi di mana berbagai pendapat yang dikeluarkannya menjadi pegangan atau acuan bagi umat Islam.

Dalam hal ini, tentu saja kriteria yang mendasari mengapa fatwa personal ini dapat diterima juga tidak dapat dikaulifikasi secara kuantitatif. Penerimaan ini terkait dengan public image atas seorang ulama. Ketika ulama dijadikan referensi dalam berbagai persoalan umat Islam, maka secara otomatis ulama tersebut akan dinilai sebagai ulama dan pendapatnya akan diikuti dan diterima sebagai sebuah fatwa. Karena itulah banyak himpunan pendapat para ulama yang bertajuk terkait dengan fatwa. Misalnya saja Al-Fatawa al-Hindiyyah, ${ }^{4}$ Majmu' al-Fatawa Ibnu Taimiyah, ${ }^{5}$

${ }^{2}$ Fatwa berarti: pendapat atau pandangan, dapat diartikan juga sebagai jawaban (hukum, pen.) terhadap masalah. Ibn Mandzur, Lisan Al-'Arab, Dar al-Ma'arif, Kahirah, h. 3364. Fatwa juga berarti “formal legal opinion" atau "advisory opinion". Baalbaki, Rohi, A Modern Arab-English Dictionary, Dar al-Elm Lilmalayin, Beirut, 2004, hlm. 815.

${ }^{3}$ Abdul Azis Dahlan, ed, Ensiklopedi Hukum Islam, Ikhtiar Baru Van Hoeve, Jakarta, 1996, hlm. 326

${ }^{4}$ Ini adalah himpunan fatwa yang disusun oleh sekumpulan ulama di India, yang mereka merupakan pengikut madzhab Hanafi. Ini dihimpun dalam, Al-Syaikh Nidham al-Din, al-Fatawa al-Hindiyyah, Dar al-Ihya al-Turath al'Arabiy, Beirut, 2002, hlm.

${ }^{5}$ Karya ini sangat monumental, merupakan himpunan fatwa yang diberikan oleh Ibnu Taimiyah, dan disusun oleh putera beliau. Fatwa-fatwa yang dimaksud ada dalam, Taqiyy al-Din Ibn 'Taimiyah, Majmu' al- Fatawa, tahqiq Musthafa Abd al-Qadir al-'Atha, vol. 1, Dar al-Kitab al-'Ilmiyyah, Beirut, 2005. 
Majmu' Fatawa, ${ }^{6}$ Fatawa Ibn Rusyd, ${ }^{7}$ Fatawa Ibn 'Aqil, ${ }^{8}$ yang merupakan himpunan dari pendapat terkait tentang berbagai aspek persoalan yang dihadapi umat Islam.

Dalam hal fatwa yang dikeluarkan tidak secara personal, maka fatwa itu dapat bermakna sebagai putusan atau pendapat hukum dari sebuah lembaga resmi yang bertugas untuk itu di sebuah pemerintahan. Tentu saja dalam hal ini adalah pemerintahan Islam. Misalnya fatwa dari lembaga fatwa tertentu di sebuah negara, seperti fatwa dari dewan ulama di sebuah negara Islam, serta termasuk juga fatwa Dewan Shariah Nasional (DSN) yang ada di Indonesia. DSN dapat diklasifikasikan sebagai lembaga fatwa yang resmi di Indonesia karena adanya regulasi yang memberikan status ataupun kewenangan untuk itu sebagaimana yang nanti akan dipaparkan dalam penjelasan berikutnya.

Dalam lingkup yang lebih luas, juga terdapat lembaga-lembaga yang merupakan badan atau himpunan dalam level internasional yang mengeluarkan fatwa, misalnya saja fatwa dari Islamic Figh Academy (Majma' al-Figh al-Islamiy), lembaga atau divsi hukum dari Organization of Islamic Conference (OIC atau OKI), ${ }^{9}$ kemudian fatwa dai AAOIFI ${ }^{10}$ (Accounting, Auditing and Governance Standards for Islamic Financial Institutions) adalah lembaga asosiasi dari berbagai lembaga keuangan Islam internasional. Atau juga, fatwa dari tokoh perorangan dalam kapasitasnya sebagai orang yang menduduki posisi tertentu yang diberikan kewenangan untuk mengeluarkan fatwa. Misalnya adalah mufti kerajaan-kerajaan (negara bagian) di Malaysia, ${ }^{11}$ mufti al-Azhar, ${ }^{12}$ dan sejenisnya.

\footnotetext{
${ }^{6}$ Ini merupakan himpunan berbagai fatwa tentang berbagai permasalahan kontemporer. Fatwa ini merupakan fatwa yang bersifat personal atau disusun oleh perorangan, bukan sebuah kelompok atau komunitas tertentu di kalangan umat Islam. Dapat dilihat pada, Muhammad ibn Shalih al-'Uthaimin, Majmu’ Fatawa, Dar al-Thurayya, Riyadh, 2005.

${ }^{7}$ Sebagaimana ulama lain yang cukup dikenal, maka Ibnu Rusyd juga merupakan ulama yang banyak dirujuk dan diikuti pendapatnya. Meski apa yang difatwakan oleh beliau merupakan pendapat pribadi, namun sebagai seorang ulama yang mu'tabar, pendapat beliau didudukkan sebagai fatwa yang memiliki kedudukan kuta dalam hukum Islam. Lihat dalam, Ibn Rusyd, Fatawa Ibn Rusyd, tahqiq, al-Mukhtar ibn Thahir al-Taliliy, Vol 1, Dar al-Gharb al-Islamiy, Beirut, 1987.

${ }^{8}$ Kitab ini juga merupakan himpunan fatwa yang menjadi banyak rujukan. Ditulis dalam madzhab Syafii. Lihat, Abdullah al-'Aziz ibn 'Aqil, Fatawa Ibn 'Aqil, Dar Ibn al-Jauziy, Riyadh, 2000.

${ }^{9}$ International Fiqh Academy, pada, www.oic.org Akses 28 April 2014

${ }^{10}$ Accounting, Auditing and Governance Standards for Islamic Financial Institutions (AAOIFI). (2002). Governance Standard for Islamic Financial Institutions No.2, on Shariah Review. Keseluruhan buku ini merupakan himpunan dari berbagi keputusan hukum atas berbagai persoalan aktual di bidang keuangan Islam (syariah). Adapun para ahli yang merumuskan atau memutuskan adalah yang tergabung dalam lembaga ini juga, yang terdiri dari para ahli dari berbagai negara di dunia.

${ }^{11}$ Di Malaysia, hampir semua negara bagian yang ada memiliki kerajaan. Dan sebagaimana kewenangan masingmasing kerajaan mencakup permasalahan agama Islam, maka memang pada negara bagian-negara bagian tersebut terdapat jabatan mufti. Sehingga ada 14 jabatan mufti di Malaysia pada tingkat negeri (negara bagian). Lihat dalam Mufti dan Jawatankuasa Fatwa Negeri-Negeri dalam www.e-fatwa.gov.my akses akses 28 April 2014.

${ }^{12}$ Mufti Al-Azhar, yang saat ini dijabat oleh Dr. Ahmed al-Tayyeb, adalah sebuah posisi yang sangat prestisius di Mesir. Lihat, Dr. Ahmed Al-Tayyeb-Grand Imam of Al-Azhar dalam www.alazhar.gov.eg/akses 28 April 2014.
} 
Di luar lembaga resmi dari pemerintah tersebut, tidak tertutup kemungkinan juga terdapatnya lembaga fatwa yang berada di suatu masyarakat (negara) yang bersifat lembaga non pemerintah. Di Indonesia, dengan banyaknya berbagai organisasi masa yang berlatar belakang keagamaan, juga telah memberikan warna bagi keberadaan fatwa. Nahdhatul Ulama (NU) dan Muhammadiyah adalah dua contoh dari organisasi masa atau sosial keagamaan ${ }^{13}$ yang dipandang paling populer dikarenakan jumlah pengikut atau anggotanya sangat besar.

Masing-masing organisasi tersebut, dalam mensikapi berbagai permasalahan tertentu, secara umum dapat dikatakan bahwa mereka juga mengeluarkan fatwa. Misalnya saja adalah fatwa yang dikeluarkan oleh kedua organisasi tersebut terkait status hukum riba. Muhammadiyah mengeluarkan putusan atau fatwa tentang haramnya riba pada tahun 2006. ${ }^{14}$ Sedangkan Nahdhatul Ulama, pada 1992 juga mengeluarkan putusan atau fatwa terkait riba, meskipun belum sampai haram secara mutlak. ${ }^{15}$ Di samping itu, terdapat juga lembaga fatwa non pemerintah yang terdapat di berbagai tempat atau kawasan. Misalnya saja Fatwa dari European Council for Fatwa and Research (Al-Majlis al-Aurubiy li al-Ifta wa al-Buhuts), yang berperan dalam memberikan fatwa bagi umat Islam di Eropa. ${ }^{16}$ Sebagaimana telah banyak diketahui, bahwa negara-negara di wilayah Eropa bukanlah negara Islam, bahkan untuk saat ini dapat dikatakan sebagai negara sekuler. Namun karena berbagai faktor, di wilayah tersebut pun akhirnya didirikan lembaga yang dapat memberikan fatwa bagi berbagai permasalahan yang dihadapi. Dapat saja pertimbangannya adalah karena komunitas muslim yang ada di wilayah tersebut memerlukan acuan atas berbagai permasalahan yang dihadapi, namun dapat juga karena kepentingan pasar atau industri, misalnya untuk dapat memberikan sertifikasi halal bagi produk makanan dari Eropa yang akan diperdagangkan di negara-negara muslim.

Fatwa adalah pendapat hukum yang dikeluarkan oleh perorangan atau lembaga tertentu yang memiliki tujuan atau tugas untuk memberikan berbagai pendapat tentang persoalan terkait aspek-aspek kehidupan dengan ditinjau dari prisip-prinsip

${ }^{13}$ Noer, Deliar. Gerakan Modern Islam di Indonesia, Pustaka Lembaga LP3ES, Jakarta, 1990, hlm. 85-95 (terkait dengan Muhammadiyah) dan 241-260 (terkait dengan Nahdhatul Ulama).

${ }^{14}$ Misalnya saja, fatwa tentang Riba oleh Muhammadiyah atau NU. Pernyataan tentang larangan (keharaman) bunga bank (riba) oleh Fatwa Manjelis Tarjih Muhammadiyah No. 8 Tahun 2006, diterbitkan pada bulan Juni 2006. Republika, 22 Agustus 2006.

${ }^{15}$ Keputusan dan Munas Alim Ulama dan Konbes NU 1992 in Bandar Lampung, dalam, Muhammad Syafi’i Antonio, Bank Syariah dari Teori ke Praktek, Gema Insani Press, Jakarta, 2001, hlm. 63-64.

${ }^{16}$ Al-Majlis al-Aurubiy li al-Ifta wa al-Bubuts, dalam, www.cfr.org/new akses 28 April 2014. 
syariah atau ajaran Islam. Sudah barang tentu, fatwa dari organisasi massa semacam ini lebih ditujukan kepada para anggota atau simpatisan organisasi tersebut, ataupun juga pada komunitas muslimin di wilayah tersebut. Sehingga, fatwa ini juga memiliki maksud yang sangat terbatas.

Melihat hal itu, maka fatwa yang dikeluarkan oleh Majelis Ulama Indonesia (MUI) terkait berbagai permasalahan yang dihadapi umat Islam masuk ke dalam kriteria fatwa oleh lembaga tertentu yang di luar pemerintah. Hal ini disebabkan bahwa MUI adalah lembaga yang bersifat non pemerintah. MUI adalah organisasi yang didirikan oleh dan atas aspirasi berbagai organisasi massa keislaman di Indonesia. MUI didirikan pada tanggal 26 Juli 1975 oleh sekelompok ulama dan pemimpin umat Islam yang berjumlah 26, yang mewakili 26 propinsi yang ada, 10 ulama yang mewakili berbagai organisasi massa umat Islam yang ada, 4 ilmuwan muslim dari berbagai lembaga pemerintah, dan sisanya 13 orang yang terdiri dari ilmuwan dan pemimpin. ${ }^{17}$

Latar belakang historis menunjukkan bahwa MUI bukanlah sebuah lembaga yang didirikan oleh pemerintah dan juga bukan merupakan sebuah lembaga pemerintah. Karenanya, fatwa yang dikeluarkan juga tidak memiliki efek legalitas sebagaimana putusan pemerintah. Hanya bedanya, jika organisasi massa semacam Nahdhatul Ulama atau Muhammadiyah tersebut diarahkan bagi umat Islam di dalam wadah organisasi tersebut, sedangkan MUI ditujukan bagi keseluruhan umat Islam di Indonesia.

\section{Mekanisme Penerbitan Fatwa DSN}

Adapun fatwa yang dikeluarkan atau diterbitkan oleh Dewan Syariah Nasional (DSN), memiliki partikularitas jika dibandingkan dengan fatwa dari organisasi atau lembaga kewilayahan seperti yang dipaparkan di atas. Partikularitas ini terletak pada kelembagaannya serta proses dan mekanisme penerbitan fatwanya. Dalam penerbitan fatwa oleh DSN, terdapat prosedur yang telah diatur secara baku. Ada dua macam cara atau proses dan prosedur bagi lahirnya sebuah fatwa. Yang pertama adalah fatwa yang dibuat atas inisiatif dari DSN, dan yang kedua, fatwa yang lahir karena permohonan yang diajukan oleh lembaga keuangan syariah tertentu. Dalam kasus model pertama, tentunya prosedur yang dilakukan lebih singkat dan

\footnotetext{
${ }^{17}$ See, Tentang Kami, in, <http://www.mui.or.id/mui in/about. > accessed, May 3, 2007.
} 
sederhana. Jika dalam situasi tertentu terjadi suatu kasus atau praktek transaksi tertentu terkait dengan perbankan atau keuangan syariah, maka DSN dapat merespon dalam bentuk penerbitan fatwa yang dimaksudkan untuk menjadi panduan dalam transaksi yang dimaksud.

Berbagai fatwa yang berjenis ini muncul dalam awal-awal perkembangan bisnis keuangan syariah di Indonesia, bukan saja khusus terkait perbankan syariah. Ialah pada fase sejarah di mana lembaga pemerintah belum memberikan dorongan yang optimal bagi tumbuh dan berkembangnya industri keuangan syariah di Indonesia. Sehingga berbagai fatwa yang dikeluarkan lebih disebabkan karena berbagai problem harus mendapat landasan dan sekaligus solusinya dari segi prinsip atau dasar syariah. Ini merupakan kwajiban moral bagi DSN dalam mengawal praktik perbankan syariah di tanah air.

Adapun dalam kasus yang kedua, penerbitan fatwa harus melalui proses yang berbeda, dan memiliki tahapan-tahapan yang tidak sederhana. Penerbitan fatwa harus didahului dengan adanya aplikasi dari pihak perbankan yang memiliki proposal tentang rancangan produk baru yang terkait dengan isu hukum Islam (syariah) dan tidak dapat diselesaikan oleh Dewan Pengawas Syariah (DPS) yang ada pada bank tersebut. Maka berdasarkan aplikasi yang disampaikan oleh pimpinan bank tersebut, DSN merespon dengan penerbitan fatwa. ${ }^{18}$

Adapun tahapan dalam penerbitan fatwa ada empat langkah sebagaimana uraian berikut:

Pertama, DSN mengadakan pertemuan yang mengundang semua anggota DSN, Pihak Bank Indonesia. Dalam hal proposal berasal dari bank pemohon, maka pihak bank juga akan diundang untuk memaparkan rancangan produk yang dimohonkan fatwa atasnya.

Kedua, hasil dari pertemuan umum tersebut dalam tahap pertama kemudian dibawa ke dalam sebuah forum pembahasan yang intensif. Dalam tahapan ini, hanya para anggota dari dewan eksekutif dari Dewan Syariah Nasional (DSN) yang dilibatkan. Pertemuan ini memang sangat terbatas dengan maksud untuk menjaga independensi dari pembahasan yang dilakukan.

Ketiga, hasil dari pertemuan khusus dalam tahapan kedua di atas kemudian didiskusikan dalam pertemuan umum. Pihak-pihak yang terkait dengan masalah

\footnotetext{
${ }^{18}$ Agus Triyanta, Shariah Compliance in Islamic Banking; Comparative Study between Malaysia and Indonesia, PhD Thesis at International Islamic University Malaysia, 2009, hlm. 286-288
} 
yang diajukan tersebut diundang dengan tujuan untuk memastikan bahwa mereka memahami sepenuhnya rancangan fatwa yang dibuat. Meskipun demikian, tidak tertutup bagi berbagai masukan dari pihak-pihak lain untuk untuk dipertimbangkan dalam pertemuan ini.

Keempat, pertemuan untuk melakukan finalisasi draft. Dalam tahap ini berbagai saran dan tanggapan yang muncul dalam pertemuan/rapat umum yang kedua kemudian diakomodasikan dalam proses akhir dan draft/rancangan dari fatwa. Pertemuan ini sangat terbatas. Untuk finalisasi draft dari fatwa tersebut, pertemuan khusus bagi anggota ekskutif saja yang diundang. Ini adalah tahap akhir dari keseluruhan proses, dan apabila telah melalui tahapan ini, maka fatwa kemudian secara resmi dikeluarkan. ${ }^{19}$

Terlepas dari unsur akibat hukum yang ditimbulkannya, penerbitan fatwa sebagaimana prosedur di atas juga layak mendapat catatan. Dengan adanya proposal yang diajukan oleh pihak bank, di mana DSN sendiri adalah lembaga yang tidak didanai oleh pemerintah, maka terbuka kemungkinan adanya bantuan dari pihak bank yang berkepentingan. Dalam konteks ini, maka dikhawatirkan terjadinya konflik kepentingan dalam penerbitan fatwa oleh DSN.

Bahkan, lain dari pada itu, keberadaan anggota DPS yang berada pada dunia industri (perbankan), yang dalam masa yang sama memiliki keanggotaan rangkap sebagai anggota dari DSN juga, menjadi persoalan tersendiri. Hal ini jelas, karena DPS ikut bertanggung jawab sebagai pihak yang mengajukan proposal untuk penerbitan sebuah fatwa baru, sedangkan DSN adalah lembaga di mana proposal tersebut ditujukan. Karena DSN kemudian akan mengeluarkan fatwa atas hal yang diajukan dalam proposal, maka dapat disimpulkan berarti ada konflik kepentingan, karena pihak yang memohon dikeluarkan fatwa juga menjadi bagian dari penerbit fatwa. Memang secara kenyataan, selama ini belum ada keberatan terhadap hal ini, namun secara kelembagaan, hal ini memerlukan perhatian yang lebih guna perbaikan (reformasi) kelembagaan dalam rangka mendukung netralitas dan independensi, baik bagi DPS maupun bagi DSN.

\section{Legalitas (Kekuatan Mengikat) dari Fatwa DSN}

Di dalam lingkup Majelis Ulama Indonesia (MUI) sendiri, terdapat beberapa lembaga yang merupakan afiliasi dan sekaligus dinaungi oleh MUI. Dewan Syariah 
Nasional (DSN) adalah salah satu dari lembaga yang dibentuk dan berada di bawah struktur organisasi MUI. ${ }^{20}$ Dengan mempertimbangkan posisi dari MUI sendiri yang tidak merupakan lembaga pemerintahan, atau lembaga resmi negara, maka sangat mudah untuk diambil kesimpulan, bahwa keputusan apapun yang dikeluarkan oleh lembaga ini adalah keputusan yang tidak memiliki kekuatan hukum mengikat bagi umat Islam atau rakyat secara umum. Dengan kata lain, kekuatannya hanya sebatas bersifat moral.

Namun yang cukup aneh, jika fatwa MUI secara umum, ialah fatwa yang dikeluarkan oleh Komisi Fatwa bukanlah bersifat mengikat, namun berbeda halnya dengan fatwa yang diberikan oleh lembaga yang merupakan bagian atau afiliasi dari MUI, ialah DSN. DSN merupakan lembaga yang fatwanya telah mendapat legalisasi dari peraturan perundang-undangan yang ada bersifat mengikat bagi lembaga keuangan dan pemerintah dalam hal transaksi ekonomi syariah. Dalam Pasal 26 ayat (2) UU tentang Perbankan Syariah dinyatakan, "Prinsip Syariah sebagaimana dimaksud pada ayat (1) difatwakan oleh Majelis Ulama Indonesia." ${ }^{21}$ Hal ini secara tegas telah memberikan legalitas bahwa fatwa yang dikeluarkan oleh DSN MUI memiliki kedudukan hukum yang sangat kuat, karena secara otomatis fatwa yang dikeluarkan telah memiliki kekuatan hukum mengikat. Bahkan tidak menunggu untuk diadopsi ke dalam Peraturan Bank Indonesia fatwa tersebut telah bersifat mengikat secara otomatis. ${ }^{22}$ Memang di sinilah keunikan dalam permasalahan fatwa di Indoneisa.

Mengapakah DSN kemudian menjadi satu-satunya lembaga yang fatwanya menjadi rujukan bagi praktek bisnis perbankan syariah di Indonesia, tentunya ada latar belakang historis yang menjadi alasannya. Jika dilihat dari kronologi kemunculan perbankan syariah di Indonesia, ialah dengan mulai beroperasinya Bank Muamalat Indonesia (BMI) 1992, perangkat hukum yang mendasari dan mengawal keberadaan perbankan syariah dapat dikatakan sangat minim. Bahkan, suatu hal yang sangat tragis jika dilihat sebenarnya BMI dari segi ekonomi sudah

${ }^{20}$ MUI memiliki berbagai lembaga yang dibentuk dan berada di bawah MUI, yaitu Lembaga Pengkajian Pangan, Obat dan Kosmetika) (LPPOM), Badan Arbitrase Syariah Nasional (Basyarnas), Lembaga Pemuliaan Lingkungan Hidup dan Sumber Daya Alam (PLH-SDA), serta Dewan Syariah Nasional (DSN). Dalam Majelis Ulama Indonesia, www.mui.or.id akses, 9 Mei 2014.

${ }^{21}$ UU No. 21 Tahun 2008 tentang Perbankan Syariah. Sedang pada ayat (3) dinyatakan "Fatwa sebagaimana dimaksud pada ayat (2) dituangkan dalam Peraturan Bank Indonesia.”

${ }^{22}$ Sementara pendapat menyatakan bahwa diadopsinya fatwa DSN MUI ke dalam PBI hanya untuk kepentingan implementasi lebih lanjut dari fatwa. Ja'far Baehaqi, "Dialektika Hukum Islam dan Hukum Nasional dalam Formulasi Hukum Perbankan Syariah di Indonesia", Disertasi pada Program Doktor Ilmu Hukum Universitas Diponegoro, 2013, hlm. 482. 
feasible untuk beroperasi sejak 1991, namun dikarenakan regulasi yang ada belum memberikan peluang, maka kemudian baru dapat beroperasi pada $1992 .{ }^{23}$ Hal itu setelah dilakukannya amandemen Undang-Undang Pokok Perbankan menjadi Undang-Undang No. 7 Tahun 1992 tentang Perbankan.

Dalam kondisi keterbatasan dukungan regulasi inilah maka Majelis MUI, yang juga sebagai salah satu pendorong utama, atau bahkan yang ikut membidani kelahiran BMI sebagai bank syariah pertama, kemudian berinisiatif untuk membentuk sebuah lembaga yang bernaung di bawah MUI, yang dinamai dengan DSN, yang berfungsi untuk memberikan fatwa terkait dengan berbagai permasalahan di bidang ekonomi syariah. Sejak itulah, maka DSN kemudian selalu memberikan pendapat hukum dalam bentuk fatwa jika lembaga keuangan memerlukannya, ataupun jika berdasarkan realita yang ada dipandang perlu adanya fatwa bagi praktik perbankan syariah di tanah air.

Karena peran DSN yang semacam itulah, kemudian regulasi yang ada pun memberikan afirmasi bahwa fatwa DSN lah yang harus dirujuk dalam hal transaksi keuangan syariah. Karena itulah maka yang dinilai sebagai tafsiran yang resmi atas berbagai prinsip syariah yang diterapkan dalam perbankan syariah adalah apa yang diputuskan atau difatwakan oleh lembaga ini, bukan lembaga lain yang ada di Indonesia ini, meskipun sebenarnya cukup banyak lembaga yang mampu dan sering mengeluarkan fatwa. ${ }^{24}$

Namun jika secara spesifik dikaitkan dengan kemengikatan fatwa tentu saja tidak sesederhana itu. Karena hal ini menyangkut otoritas yang bersumber pada kekuasaan pemerintah. Sebagaimana telah jelas dalam diskusi di atas, bahwa penerbitan fatwa dalam bidang keuangan syariah di Indonesia dilakukan oleh DSN. Jika dilihat dari sudut pandang kelembagaan, sebenarnya posisi DSN ini agak unik untuk menjadi sebuah lembaga yang memiliki kewenangan untuk mengeluarkan fatwa. Ini adalah lembaga non pemerintah, yang pada lazimnya tidak memiliki otoritas untuk mengeluarkan putusan atau yang dalam hal ini adalah fatwa, yang konskuensi hukumnya bersifat mengikat. Namun untuk kasus DSN ini, apa yang

\footnotetext{
${ }^{23}$ Sinansari Ecip, Syu'bah Asa and Evesina, Ketika Bagi Hasil Tiba, Perjalanan 10 Tabun Bank Muamalat, Muamalat Institute, Jakarta, 2002, hlm. xiv-xvi. Adiwarman A. Karim, "Para Pejuang Ekonomi Syariah", Republika, 23 Mei 2005. Muhammad Syafi'i Antonio. Bank Syariah dari Teori ke Praktik, Gema Insani Press, Jakarta, 2001, hlm. 25.

${ }^{24}$ Berbagai organisasi masa Islam, seperti Nahdhatul Ulama, Muhammadiyah, Persatuan Islam, dan sebagainya, masing-masing memiliki lembaga yang khusus menangani berbagai persoalan yang dihadapi anggotanya (umat) dengan cara memberikan fatwa.
} 
difatwakan oleh DSN sebagaimana telah jelas dalam pemaparan di atas, kemudian menjadi suatu sumber yang harus dirujuk oleh perbankan syariah.

Pada dasarnya fatwa bukanlah suatu produk norma yang mengikat. Kepatuhan seseorang terhadap fatwa bersifat sukarela (voluntary). Itu dalam konsep dasar tentang fatwa dan kekuatan hukumnya. Akan tetapi adakalanya fatwa dengan jenis khusus, yaitu jika fatwa itu dikeluarkan oleh sebuah lembaga yang mendapatkan kewenangan atau otoritas khusus untuk itu, fatwa dapat memiliki efek hukum lain, yakni dapat memiliki konsekuensi hukum yang mengikat. Sehingga, jika dilihat bahwa fatwa DSN itu mendapatkan justifikasi legal dari regulasi yang ada, maka fatwa itu menjadi memenuhi syarat dalam fikih sebagai sebuah fatwa 'ala thabi'ah khashshah" ialah fatwa yang memiliki sifat spesifik, yang sudah barang tentu akan keluar dari sifat fatwa secara umum. ${ }^{25}$

Lantas, bagaimanakah justifikasi hukum dari regulasi yang dimaksud? Ada dua pendekatan yang dapat dijelaskan untuk menunjukkan justifikasi legal ini. Pertama, bahwa sebagaimana telah disebut dalam Undang-Undang No. 21 Tahun 2008 tentang Perbankan Syariah, Pasal 26 ayat (2) menyatakan bahwa yang dimaksud dengan "prinsip syariah" adalah sebagaimana yang dikeluarkan dalam fatwa oleh DSN. ${ }^{26}$ Klausula tersebut memberikan efek hukum bahwa fatwa DSN merupakan satu-satunya referensi terkait prinsip syariah dalam bisnis perbankan syariah yang harus digunakan, dan karenanya secara otomatis apa yang di fatwakan akan menjadi suatu ketentuan hukum yang harus dirujuk.

Menggunakan ungkapan yang berbeda dapat juga disimpulkan, bahwa lembaga perbankan syariah di Indonesia bukan saja harus merujuk pada fatwa DSN, dan lebih dari itu malah terikat dengan fatwa DSN. Mengapa demikian, hal ini dikarenakan bank syariah berkewajiban untuk menerapkan prinsip syariah dalam produk dan operasionalnya, sedangkan prinsip syariah yang harus diterapkan adalah prinsip aturan dalam hukum Islam yang difatwakan oleh DSN. Atas dasar itulah maka, secara tidak langsung, lembaga perbankan syariah berkewajiban untuk menjalankan apa yang di fatwakan oleh DSN.

Kedua, jika dinilai bahwa DSN itu bukan lembaga pemerintahan, yang karenanya semua produk hukum yang dikeluarkannya berarti tidak memiliki fungsi regulatif,

25 'Abd al-Hamid al-Ba'li, “Taqnin A'mal al-Hai'at al-Syar'iyyah: Ma'alimuh wa 'Aliyatuh.” Paper presented in alMu'tamar al-Thalith li al-Hai'at al-Syar'iyyah li al-Mu'assasat al-Maliyah al-Islamiyyah, 5-6 Oktober, 2003 in Bahrain, hlm. 46-47.

${ }^{26}$ Undang-Undang No. 21 Tahun 2008 tentang Perbankan Syariah, Pasal 26 ayat (2) selengkapnya berbunyi: "Prinsip Syariah sebagaimana dimaksud pada ayat (1) difatwakan oleh Majelis Ulama Indonesia" 
maka, fatwa yang dikeluarkannya tidaklah memiliki fungsi mengikat secara hukum. Namun, sejak awal dari praktik perbankan syariah di negeri ini, Bank Indonesia, melalui Direktorat Perbankan Syariah, selalu memproses fatwa menjadi regulasi. Atas dasar itulah maka kemudian fatwa itu diadopsi menjadi Peraturan Bank Indonesia. Dengan diadopsinya fatwa menjadi Peraturan Bank Indonesia, maka substansi fatwa itu menjadi hukum materiil yang mengikat bagi industri perbankan. Jadi dalam hal ini yang memiliki kekuatan mengikat bukanlah fatwa itu sendiri akan tetapi Peraturan Bank Indonesia itulah yang memiliki kekuatan mengikat.

Jadi, jika dilihat dari perspektif yang kedua ini, maka substansi dari fatwa yang dikeluarkan oleh DSN memiliki kekuatan hukum mengikat karena telah dilegalisasi dengan Peraturan Bank Indonesia. Tentu saja dalam hal ini adalah substansi fatwa dan bukan format fatwa itu yang kemudian memiliki kekuatan hukum mengikat. Bagaimanapun juga, dari uraian tersebut di atas menunjukkan bahwa jika akan diterapkan perspektif yang pertama, fatwa akan berfungsi mengikat, dan jika akan diterapkan perspektif yang kedua, maka substansi fatwa itulah yang kemudian akan diformat dalam sebuah PBI yang memiliki fungsi kekuatan hukum mengikat. Dengan kata lain, fatwa DSN pada gilirannya, akan memiliki kekuatan hukum mengikat.

Hanya saja, dalam perspektif yang kedua ini, masih ada kemungkinan bahwa sebuah fatwa tidak akan diadopsi ke dalam PBI, misalnya saja jika menurut Bank Indonesia inti atau substansi dari fatwa tersebut tidak disepakati oleh pihak Bank Indonesia. Karena, bagaimanapun juga fatwa telah dikeluarkan oleh DSN, BI tetap tidak berkewajiban untuk mengadopsinya ke dalam PBI. Dalam konteks seperti inilah maka Komite Perbankan Syariah (KPS) dibentuk, sebagai amanat dari UndangUndang Perbankan Syariah. ${ }^{27}$ Komite ini dimaksudkan sebagai lembaga yang menjadi perantara antara DSN dengan Bank Indonesia, dan tugas utama yang diembannya adalah memproses fatwa menjadi sebuah draf produk perundangundangan. Hanya dalam perjalanannya kemudian nampaknya komite ini tidak memainkan peran secara optimal. Quo vadis dari KPS yang seperti ini sebenarnya tidak mengherankan jika dilihat dari latar belakang sejarah yang terjadi. Ialah bahwa posisi DSN yang berada di bawah MUI cukup dilematis bagi Bank Indonesia atau pemerintah. Karena bukan lembaga pemerintah maka putusan yang keluar dari lembaga ini tidak memiliki kekuatan hukum.

\footnotetext{
${ }^{27}$ Pasal 26 ayat (4) UU tentang Perbankan Syariah berbunyi, "Dalam rangka penyusunan Peraturan Bank Indonesia sebagaimana dimaksud pada ayat (3), Bank Indonesia membentuk komite perbankan syariah.” Hal ini merupakan dasar bagi pembentukan Komite Perbankan Syariah.
} 
Masalah lainnya adalah koordinasi dan harmonisasi antar lembaga. Dalam arti bahwa posisi DSN yang bersifat sebagai lembaga independen memunculkan kesulitan bagi Bank Indonesia, karena keduanya merupakan lembaga yang berbeda, satunya sebagai lembaga non pemerintah dan yang satunya adalah lembaga pemerintah. Atas dasar itulah maka ada wacana pembentukan lembaga fatwa dalam lembaga negara sempat menguat pada masa-masa pasca lahirnya Undang-Undang No. 21 Tahun 2008 tentang Perbankan Syariah. Namun wacana ini mendapat penentangan keras utamanya dari kalangan DSN. ${ }^{28}$

Menjelang lahirnya Undang-Undang Perbankan Syariah terjadi perdebatan di seputar pentingnya dewan syariah yang berada di dalam struktur pemerintah. Hal ini diprediksi akan mengeliminasi berbagai macam problem, termasuk di dalamnya adalah problem legalitas atau kekuatan mengikat dari sebuah fatwa yang dikeluarkan oleh DSN. Di antara rancangan yang mewacana adalah bahwa lembaga yang memberikan fatwa, apapun lembaga tersebut akan dinamai, semestinya berada dalam struktur organisasi kelembagaan pada bank sentral (Bank Indonesia).

Adanya reposisi struktur semacam ini, maka secara otomatis, semua keputusan atau fatwa, atau apapun juga terminologi untuk menyebutnya, tidak akan mengalami masalah legalitas. Hal ini disebabkan bahwa semua keputusan yang diterbitkan oleh lembaga resmi negara akan secara otomatis memiliki kekuatan hukum mengikat. Hal ini sebenarnya juga bukan merupakan hal yang baru dalam berbagai praktek di berbagai negara. Malaysia misalnya, ${ }^{29}$ telah menerapkan hal ini semenjak awal-awal perkembangan perbankan Islam (syariah).

Sebelum lahirnya UU No. 6 Tahun 2008, memang terjadi suatu masalah yang komplikatif, ialah jika DSN mengeluarkan sebuah fatwa, namun fatwa tersebut tidak diadopsi oleh Bank Indonesia ke dalam Peraturan Bank Indonesia (PBI), maka berarti fatwa itu tidak akan memiliki kekuatan hukum mengikat. Hal ini terjadi misalnya pada 2006 di mana salah satu fatwa DSN, yang sempat dipending untuk tidak segera diadopsi ke dalam PBI. ${ }^{30}$ Namun, hal ini sekarang tentu tidak akan menjadi masalah karena DSN menjadi lembaga yang ditunjuk oleh hukum dan perundang-undangan

28 "DSN-MUI Tolak Komite Perbankan Syariah," dalam Hukumonline, http:/ / www.hukumonline.com tanggal 29 Juni 2007, akses 12 Mei 2014.

${ }^{29}$ Di Malaysia, lembaga yang mengeluarkan shariah opinion atau fatwa adalah Shariah Advosory Council yang berada dalam struktur Bank Sentral (Bank Negara Malaysia), dan bertanggungjawab kepada Gubernur Bank. Putusan yang dikeluarkan secara resmi disebut dengan shariah resolution, dan bukannya disebut fatwa. Central Bank of Malaysia, Shariah Resolutions in Islamic Finance, Kuala Lumpur, 2007.

${ }^{30}$ Bank Indonesia, Laporan Perkembangan Perbankan Syariah 2005, Jakarta, 2006, hlm. 77-78. 
sebagai lembaga yang fatwa nya dalam bidang ekonomi syariah menjadi rujukan yang mengikat bagi lembaga keuangan syariah yang ada di Indonesia.

\section{Fatwa Compaint dalam Tradisi Hukum Islam}

Sebelum sampai pada pembahasan tentang kemungkinan bagi dilakukannya apa yang disebut dengan judicial review bagi fatwa, penting untuk terlebih dahulu dilihat, bagaimanakah sebenarnya tradisi hukum Islam melihat supremasi dari fatwa, dan kemungkinannya terhadap upaya kritis atau semacam 'gugatan' terhadap sebuah fatwa. Untuk melakukan analisa dalam konteks ini, maka perlu dilihat beberapa aspek yang berkaitan dengan fatwa, yang akan dapat dijadikan parameter dalam menentukan ada atau tidaknya konsep semacam fatwa complaint dalam tradisi Islam. Dengan kata lain, bagaimana keberatan terhadap lahirnya suatu fatwa itu akan dapat diberikan ruang untuk mengakomodasinya, dalam tradisi dan sejarah perkembangan hukum Islam. Untuk itu, minimal ada tiga hal yang harus dipahami:

Pertama, adanya konsep khilafiyah atau ikhtilaf. Sebagai telah menjadi mafhum, bahwa tradisi berbeda pendapat dalam aspek tertentu dari Hukum Islam atau fikih adalah hal yang sangat jamak terjadi di kalangan umat Islam. Islam mengenal konsep khilafiyah atau ilkhtilaf, yaitu perbedaan pandangan dalam ajaran Islam. Jika dalam konteks fikih, maka itu berarti perbedaan pendapat dalam bidang hukum Islam. Dikenalnya konsep tersebut menunjukkan bahwa dalam Islam yang namanya perbedaan pandangan dalam hukum adalah suatu hal yang bukan saja wajar, namun merupakan suatu kemestian yang akan terjadi. Karena itulah maka perbedaan tersebut mesti direspon dan disikapi dengan cara yang sedemikian rupa agar kondusifitas dalam pengamalan atau implementasi hukum Islam tetap terjaga.

Menurut konsep ini, perbedaan terjadi ketika masing-masing pandangan memiliki argumen yang memang valid dan reliable. Artinya, perbedaan tidak akan masuk dalam klasifikasi apa yang disebut dengan khilafiyah atau ikhtilaf jika saja alasan yang diajukan tidak dapat dipertanggungjawabkan. Atau sebuah pendapat yang berbeda dari fatwa atau pendapat lain yang hanya beralaskan pada 'asal berbeda,' tidak akan dapat disebut sebagai fenomena ikhtilaf atau khilafiyah.

Karena itulah, maka perbedaan yang ada dalam konteks ini adalah perbedaan yang dapat dikatakan sebagai bersifat positif, ialah pengayaan perspektif dalam menentukan interpretasi atas suatu teks. Sehingga, keberadaan konsep khilafiyah merupakah salah satu bentuk penghargaan atas upaya tertinggi yang dicurahkan 
oleh seseorang atau sekelompok orang dalam memahami dan memformulasikan suatu ketentuan hukum.

Keberadaan konsep khilafiyah atau ikhtilafini menunjukkan bahwa sebuah upaya untuk men-counter sebuah pendapat hukum diniscayakan dalam Islam. Dengan kata lain, pendapat tandingan atas pendapat yang telah muncul sebelumnya, atau telah mapan, adalah pendapat yang tetap dapat diakui, tidak dianggap sebagai sebuah pendapat hukum yang liar atau illegal.

Kedua, konsep amar ma'rufnahi munkar. Ini merupakan konsep yang sangat general sifatnya. Dan aplikasinya pun dapat dilakukan dalam pada ranah apa saja dalam Islam. Secara literal, amar ma'ruf nahi munkar bermakna, "memerintahkan yang baik dan melarang yang munkar," dan secara terminologis dimaksudkan untuk menegakkan aturan kebenaran dengan cara memerintahkan, menjunjung tinggi kebaikan dan kebenaran serta melakukan upaya pencegahan atas semua bentuk kemunkaran atau penyelewengan dari nilai kebenaran.

Generalitas cakupan ketentuan ini menjadikan bahwa dalam Islam, setiap orang berkewajiban untuk melakukan semua upaya tegaknya kebenaran dan berkewajiban untuk mencegah terjadinya kesalahan. Konsep ini memang akhirnya menjadi konsep yang unik dan khas. Karena penegasan atas hal ini muncul dari dalil-dalil yang valid, yang akhirnya menjadikan amar ma'ruf nahi munkar sebagai sebuah conditio sine qua non bagi terwujudnya masyarakat muslim yang ideal.

Keberadaan konsep ini, jika dikaitkan dengan adanya upaya bagi fatwa complaint tersebut adalah bahwa sebuah fatwa yang dikeluarkan oleh siapa atau lembaga apa saja, tidak akan pernah dapat diposisikan sebagai bebas dari obyek analisa dan kritik guna perbaikan. Dari analisa tersebut, jika dijumpai kesalahan di dalamnya, maka bukan saja sekedar diperbolehkan, bahkan diwajibkan bagi siapa saja yang menemukan kesalahan yang terjadi untuk menyampaikan upaya perbaikannya. Hal ini demi terjaganya kebenaran dan terhindarnya setiap muslim dari kesalahan atau kemunkaran. Sebaliknya, sikap mendiamkan suatu pendapat hukum, fatwa, ataupun opini hukum yang salah merupakan tindakan atau sikap yang dikecam oleh Islam, dan memiliki konsekuensi dosa. Atas dasar itulah maka adalah wajar dan sah menurut prinsip-prinsip hukum Islam jika sebuah fatwa dikritik atas kesalahannya dan kemudian diajukan upaya pembenarannya.

Ketiga, konsep tentang jidal. Jidal memiliki makna sebagai perdebatan atau beradu argumentasi. Dalam hukum Islam, konsep ini dikenal sebagai kelanjutan dari adanya 
konsep ikhtilaf dan amar ma' rufnahi munkar di atas. Jika dalam ikhtilaf mengindikasikan bahwa di dalam Islam atau Hukum Islam perbedaan pandangan dinilai sebuah keniscayaan dan kewajaran, dan karenanya absah untuk diikuti, maka dalam amar ma'ruf nahi munkar dan konsep jidal, lebih maju dari itu. Konsep amar ma'ruf nahi munkar mengaksentuasikan bahwa kesalahan yang terjadi atas sebuah pendapat hukum haruslah diluruskan, dan metode pelurusannya adalah dengan konsep jidal.

Untuk itu, jidal lebih merupakan sebuah upaya atau tindakan untuk berdialektika menemukan kebenaran. Beradu argumentasi secara baik menjadi salah satu dari yang diprioritaskan oleh Islam dalam terjadi perbedaan pandangan atau pendapat. Bahkan dalam konteks perbedaan keyakinan atau agama, jidal yang dilakukan dengan cara yang baik (ahsan) adalah suatu anjuran. ${ }^{31}$ Karena itulah, keberadaan konsep ini dalam Islam atau khususnya dalam hukum Islam adalah suatu indikasi bahwa mencari titik temu, mengungkapkan kelemahan dan memberikan argumentasi yang lebih tepat atas suatu opini hukum adalah hal yang baik.

Melalui tiga konsep tersebut, yakni, khilafiyah atau ilkhtilaf, amar ma'ruf nahi munkar, serta jidal, membuktikan bahwa ada indikasi yang dengan jelas menunjukkan bahwa upaya bagi tindakan fatwa complaint adalah hal yang sah untuk dilakukan. Dalam arti, jika ada sebuah fatwa atau opini hukum Islam dalam aspek tertentu, dan dipandang ada kesalahan, maka fatwa atau opini hukum Islam tersebut dapat dipertanyakan. Jika mempertanyakan dalam hal ini saja dinilai sah, maka dalam konteks sistem ketetanegaraan, judicial review terhadap produk hukum yang dikeluarkan atau dibuat oleh lembaga yang oleh hukum diberikan status kekuatan mengikat, sangat mungkin dilakukan.

\section{Kemungkinan Permohonan Judicial Review bagi Fatwa}

Salah satu karakteristik yang khas pada sebuah produk hukum adalah keniscayaannya untuk dilakukan keberatan (gugatan). Selama ini, bentuk dari gugatan yang dimaksud adalah judicial review, atau peninjauan kembali. Judicial review ini utamanya dalam hal materiil, ialah kandungan materi hukum yang terkandung dalam sebuah produk hukum, dalam hal ini adalah materi fatwa tersebut. ${ }^{32}$

${ }^{31}$ Hal ini ditegaskan dalam ayat al-Qur'an, surat Al-Nahl ayat 125 yang berbunyi: “" Serulah (manusia) kepada jalan Tubanmu dengan hikmah, dan pengajaran yang baik, berdebatlab dengan mereka dengan cara yang baik..." 
Misalnya saja, jika sebuah keputusan atau peraturan dari sebuah institusi negara, atau sebuah produk hukum yang berfungsi mengikat dari lembaga tersebut, maka kemudian peraturan atau keputusan tersebut dapat dimohonkan peninjauan hukum jika dipandang ada kelemahan atau cacat dalam putusan atau aturan tersebut. Dengan mekanisme tersebut, maka sebuah lembaga harus berhati-hati jika dalam mengeluarkan sebuah putusan atau aturan hukum, dalam arti harus berupaya untuk menghindari berbagai kelemahan yang membuka peluang bagi kemungkinan untuk di lakukan gugatan.

Terkait dengan fatwa, maka sangat menarik untuk dilihat, apakah fatwa yang sesuai dengan karakter dan sifatnya sebagaimana didiskusikan di atas, memungkinkan untuk dilakukan gugatan dalam bentuk judicial review, misalnya. Pemikiran ini tidak mengada-ada, namun berdasarkan logika judicial review tersebut, maka sebagai sebuah putusan hukum yang memiliki fungsi mengikat, fatwa memiliki peluang untuk dilakukan tindakan tersebut.

Meski dalam kondisi yang berbeda, kasus di mana fatwa digugat melalui judicial review ini pernah terjadi di Pakistan. Terkait dengan sebuah aturan yang dikeluarkan oleh otoritas resmi dari pemerintah terkait dengan haramnya riba, pemerintah Pakistan harus menghadapi sebuah tindakan judicial review. Gugatan tersebut diajukan ke shariah court. ${ }^{33}$ Atas dasar gugatan tersebut, maka kemudian Shariah Court Pakistan mengeluarkan sebuah putusan yang pada intinya bahwa fatwa tentang haramnya bunga bank sudah benar. Dengan kata lain, putusan hakim mengalahkan pihak penggugat.

Demikian halnya dengan fatwa DSN dalam bidang perbankan syariah. Jika fatwa tersebut memiliki fungsi mengikat, maka fatwa tersebut dapat digugat dengan mekanisme sebuah judicial review. Ini memang merupakan hal yang dilematis, dan karenanya problematis. Memang masalahnya kemudian menjadi tidak sederhana, karena fatwa akan dapat dipermasalahkan. Namun inilah konsekuensi bahwa fatwa DSN memiliki fungsi mengikat.

Tentu saja, untuk dilakukan sebuah judicial review atas fatwa merupakan hal yang mengejutkan, karena akan berimplikasi pada diperlukannya sumber daya yang

32 Ada dua macam peninjauan kembali atau judicial review, ialah formil dan materiil. Formil menyangkut mekanisme dan prosedur, sedangkan materiil menyangkut tentang isi atau materi muatan. Sri Soemantri, Hak Uji Material di Indonesia, Alumni, Bandung, 1997, hlm. 11. Karena itulah dalam konteks fatwa ini lebih mengarah pada uji materiil.

${ }^{33}$ Muhammad Taqi Usmani, The Text of the Historic Judgement on Riba, The Other Press, Kuala Lumpur, 2001, hlm. iii-iv. Lihat juga sebagai perbandingan di Malaysia, Norhashimah Mohd. Yasin, "Appeal Court Decision on Bay' bi Thaman 'Ajil (BBA): Misunderstanding and/or True State of Affairs?” in Malayan Law Journal, 3, 1998, hlm. 673-674. 
dapat melakukan evaluasi atas fatwa. Karena itulah, jika judicial review itu memang menjadikan potensi permasalahan yang semakin kompleks, maka paling tidak harus disediakan mekanisme untuk judicial complaint, ialah mekanisme untuk melakukan evaluasi terhadap sebuah fatwa, dengan cara yang dipandang lebih sederhana namun tetap dapat memberikan kebaikan bagi berbagai stake holders yang terkait.

Urgensi dari perlunya adanya mekanisme judicial review ini bukan saja masalah karena fatwa telah menjadi produk hukum yang memiliki kekuatan mengikat, namun di sisi lain, para personel atau lembaga yang mengeluarkan fatwa memang semestinya bertanggung jawab atas fatwa yang dikeluarkannya. Pertanggungjawaban ini utamanya adalah pada kebenaran dari fatwa tersebut. Karena fatwa itu dalam konstelasi hukum Islam memiliki kedudukan tersendiri yang istimewa, maka menjaga agar institusi atau perlembagaan fatwa itu senantiasa berada dalam kebenaran dan sesuai proporsinya adalah suatu keharusan.

Atas dasar itulah harus diciptakan sebuah mekanisme untuk dapat mengoreksi sebuah fatwa. Adalah tidak mustahil sebuah fatwa mengandung kelemahan, yang karenanya, upaya konstruktif untuk mengoreksi dan menjaga orisinalitas dan proporsionalitas fatwa diperlukan dalam hal ini. Di samping itu, mengingat fatwa DSN ini berada atau berperan dalam konteks perbankan syariah khususnya dan ekonomi syarah pada umumnya, maka pengawasan publik dan pihak-pihak terkait sangat diperlukan untuk menjaga kemurnian fatwa dan terhindar dari berbagai vested interest yang dapat saja terjadi.

Sehingga, permohonan untuk judicial review terhadap fatwa haruslah dipahami dalam konteks semacam itu. Memang, artikel ini belum sampai berbicara bagaimana proses judicial review ini harus dilakukan, namun paling tidak memberikan suatu gambaran bahwa penting adanya mekanisme untuk menjaga agar fatwa itu tetap proporsional.

\section{Penutup}

Mendasarkan pada diskusi di atas, dapat disimpulkan bahwa fatwa adalah pendapat hukum yang dikeluarkan oleh perorangan atau lembaga tertentu yang memiliki tujuan atau tugas untuk memberikan berbagai pendapat tentang persoalan terkait aspek-aspek kehidupan dengan ditinjau dari prisip-prinsip syariah atau ajaran Islam. Sudah barang tentu, fatwa dari organisasi masa semacam ini lebih 
ditujukan kepada para anggota atau simpatisan organisasi tersebut, ataupun juga pada komunitas muslmin di wilayah tersebut. Sehingga, fatwa ini juga memiliki maksud yang sangat terbatas.

Lain dari pada itu, jika dilihat dari kekuatan mengikatnya, nampaklah bahwa fatwa DSN memiliki kekuatan hukum mengikat bagi industri perbankan syariah. Kemengikatan itu muncul karena adanya pernyataan dari regulasi yang ada bahwa hanya fatwa DSN lah yang menjadi rujukan dalam bisnis perbankan syariah. Bahkan, jika pun DSN itu dianggap sebagai lembaga non pemerintah yang karenanya semua produk aturan yang dikeluarkannya tidak memiliki kekuatan mengikat sebagaimana umumnya putusan lembaga pemerintahan, tetap saja fatwa itu akan mengikat, meskipun secara substantif, hal itu dikarenakan Peraturan Bank Indonesia terkait berbagai ketentuan perbankan syariah, jika menyangkut permasalahan syariah, adalah merupakan adopsi dari fatwa DSN.

Sebagai konsekuensi kekuatan yang mengikat tersebut, maka kemudian sebagai karakteristik sebuah regulasi pemerintah yang dapat digugat (diajukan keberatan atasnya), maka fatwa juga dapat menjadi objek dari permohonan judicial review. Sehingga, kemengikatan fatwa membawa dua pengaruh sekaligus, pengaruh positif dan negatif sekaligus. Positif dalam arti status fatwa yang relatif tinggi, dan kedua bahwa sebagai sebuah produk hukum yang memiliki kekuatan mengikat, terbuka kemungkinan bagi adanya judicial review. Hal ini jika dianalisa, sekaligus juga bertujuan untuk menjaga agar institusi (perlembagaan) fatwa terjaga kemurnian dan proporsionalisnya.

\section{Daftar Pustaka}

Accounting, Auditing and Governance Standards for Islamic Financial Institutions (AAOIFI), 2002. Governance Standard for Islamic Financial Institutions No.2, Shariah Review.

Al-Majlis al-Aurubiy li al-Ifta wa al-Buhuts, dalam, www.cfr.org/new , diakses 28 April 2014.

Antonio, Muhammad Syafi'i, Bank Syariah dari Teori ke Praktik: Gema Insani Press, Jakarta, 2001.

'Aqil, Abdullah al-'Aziz ibn, Fatawa Ibn 'Aqil, Dar Ibn al-Jauziy, Riyadh, 2000.

al-Ba'li, 'Abd al-Hamid, “Taqnin A'mal al-Hai'at al-Syar'iyyah: Ma'alimuh wa 'Aliyatuh." Paper presented in al-Mu'tamar al-Thalith li al-Hai'at al-Syar'iyyah li al-Mu'assasat al-Maliyah al-Islamiyyah, 5-6 October, 2003 in Bahrain. 
Baalbaki, Rohi, A Modern Arab-English Dictionary, Dar al-Elm Lilmalayin, Beirut, 2004.

Baehaqi, Ja'far, Dialektika Hukum Islam dan Hukum Nasional dalam Formulasi Hukum Perbankan Syariah di Indonesia, Disertasi pada Program Doktor Ilmu Hukum Universitas Diponegoro, 2013.

Bank Indonesia, Laporan Perkembangan Perbankan Syariah 2005, Jakarta, 2006.

Central Bank of Malaysia, Shariah Resolutions in Islamic Finance, Kuala Lumpur, 2007.

Dahlan, Abdul Azis, ed, Ensiklopedi Hukum Islam, Ikhtiar Baru Van Hoeve, Jakarta, 1996.

“DSN-MUI Tolak Komite Perbankan Syariah," dalam Hukumonline, http:// www.hukumonline.com tanggal 29 Juni 2007, diakses 12 Mei 2014.

Dr. Ahmed Al-Tayyeb-Grand Imam of Al-Azhar dalam www.alazhar.gov.eg/ diakses 28 April 2014.

Ecip, Sinansari, Syu'bah Asa and Evesina, Ketika Bagi Hasil Tiba, Perjalanan 10 Tahun Bank Muamalat, Muamalat Institute, Jakarta, 2002.

International Fiqh Academy, pada, www.oic.org, diakses 28 April 2014

Karim, Adiwarman A, “Para Pejuang Ekonomi Syariah”, Republika, 23 Mei 2005.

Majelis Ulama Indonesia, www.mui.or.id, diakses, 9 Mei 2014.

Mandzur, Ibn, Lisan Al-'Arab, Dar al-Ma'arif, Kahirah, Tt.

Mufti dan Jawatankuasa Fatwa Negeri-Negeri dalam www.e-fatwa.gov.my akses 28 April 2014.

Muhammad Syafi'i Antonio, Bank Syariah dari Teori ke Praktek, Gema Insani Press, Jakarta, 2001.

New Horizon, April-June, 2007.

Noer, Deliar. Gerakan Modern Islam di Indonesia, Pustaka Lembaga LP3ES, Jakarta, 1990.

Norhashimah Mohd. Yasin, "Appeal Court Decision on Bay' bi Thaman 'Ajil (BBA): Misunderstanding and/or True State of Affairs?" in Malayan Law Journal, 3, $1998,673-674$

Rusyd, Ibn, Fatawa Ibn Rusyd, tahqiq, al-Mukhtar ibn Thahir al-Taliliy, Vol 1, Dar alGharb al-Islamiy, Beirut, 1987.

Soemantri, Sri, Hak Uji Material di Indonesia, Alumni, Bandung, 1997.

Taimiyah, Taqiyy al-Din Ibn, Majmu' al- Fatawa, tahqiq Musthafa Abd al-Qadir al'Atha, vol. 1, Beirut: Dar al-Kitab al-'Ilmiyyah, 2005.

Tentang Kami, in, <http://www.mui.or.id/mui_in/about. > accessed, May 3, 2007.

Triyanta, Agus, Shariah Compliance in Islamic Banking; Comparative Study between Malaysia and Indonesia, PhD Thesis, International Islamic University Malaysia, 2009. 
Usmani Taqi , Muhammad, The Text of the Historic Judgement on Riba, The Other Press, Kuala Lumpur, 2001.

al-`Uthaimin, Muhammad ibn Shalih, Majmu’ Fatawa, Dar al-Thurayya, Riyadh, 2005. Undang-Undang No. 21 Tahun 2008 tentang Perbankan Syariah.

Republika, 22 Agustus 2006. 